\title{
The prevalence of anti-thyroid peroxidase antibodies and autoimmune thyroiditis in children and adolescents in an iodine replete area
}

\author{
M Kabelitz, K P Liesenkötter, B Stach ${ }^{1}$, H Willgerodt ${ }^{1}$, W Stäblein, W Singendonk, E Jäger-Roman, \\ H Litzenbörger, B Ehnert and A Grüters \\ University Children's Hospital Charité, Humboldt University Berlin, Augustenburger Platz 1, 13353 Berlin, Germany \\ and ${ }^{1}$ University Children's Hospital, Leipzig, Germany \\ (Correspondence should be addressed to A Grüters; Email: annette.grueters@charite.de)
}

\begin{abstract}
Background: The iodine supply of the population in Berlin has normalized during the last 5 years. Therefore autoimmune thyroiditis has become the most important differential diagnosis in children and adolescents with goiter.

Objective: The aim of the present study was to define the prevalence of anti-thyroid peroxidase (TPO) antibodies and autoimmune thyroiditis in children and adolescents with a normalized iodine intake. Design: To enable the measurement of antibodies to thyroid peroxidase (anti-TPO-Ab) in a large cohort, a method to determine anti-TPO-Ab in dried filter paper blood spots was established. In co-operation with pediatricians the antibody prevalence was assessed and data regarding thyroid size, echostructure and the medical history concerning iodine intake and familial thyroid diseases were collected.

Methods: 660 children and adolescents participated in the study; urinary iodine, TSH and TPO-Ab were measured and an ultrasound of the thyroid gland was performed.

Results: The sensitivity of the newly established filter paper assay was $91.8 \%$ and specificity was $100 \%$. The results confirmed the improved iodine supply, with a median urinary iodine concentration of $139 \mu \mathrm{g}$ iodine/g creatinine. The prevalence of anti-TPO-Ab was $3.4 \%$ with a female to male ratio of $2.7: 1$.

Conclusion: The prevalence of anti-TPO-Ab is lower or equal to data reported from other iodine sufficient areas. Data from a moderate iodine deficiency in schoolchildren range from 0.0 to $7.3 \%$. Using the new filter paper method field studies can be implemented to monitor the effect of changes in iodine nutrition on thyroid autoimmunity. Furthermore, this study on the prevalence of antiTPO-Ab in a cohort of healthy children and adolescents in an iodine replete area can serve as reference data for future investigations and for the comparison with other groups of patients with increased risks for thyroid autoimmunity.
\end{abstract}

European Journal of Endocrinology 148 301-307

\section{Introduction}

Iodine supply in Germany has improved during the last 5 years due to several efforts to increase iodine in nutrition, e.g. the use of iodized salts in bakeries as well as in the meat and food processing industries. As late as 1993 the Federal Republic of Germany was considered an iodine deficient area (grade I to grade II according to the World Health Organisation (WHO) criteria (1)) with a median urinary iodine concentration of less than $50-100 \mu \mathrm{g}$ iodine/g creatinine (grade I) or less than 25-50 $\mu$ g iodine/g creatinine (grade II) (2). In contrast to some regions in Germany iodine supply has normalized in Berlin as demonstrated in newborns
(3) and schoolchildren (4), which has resulted in a decrease in thyroid volumes and a very low frequency of goiter (4). Therefore, it can be assumed that with a normalized iodine intake causes other than iodine deficiency have to be considered in children and adolescents with thyroid enlargement. The most frequent cause of juvenile goiter in populations with a normal iodine intake is proliferate autoimmune thyroiditis (Hashimoto's thyroiditis) (5).

The etiology of autoimmune thyroiditis (AIT) remains unclear. Predisposing genetic factors (6) seem to be evident, but environmental factors (7) such as stress $(8,9)$, infections, trauma, smoking (10), drugs and nutrition, especially an increased iodine supply, 
as well as an increased age have also been shown to be conclusively linked to AIT. A four to seven times increased prevalence is observed in females (11), strongly indicating hormonal influences $(12,13)$.

In addition, iodine plays a key role in the manifestation of AIT (14), as substantiated by experimental (15-18) and epidemiological studies (19-23). So far, no studies have been presented that have assessed the influence of the increased iodine intake on the prevalence of anti-thyroid peroxidase (TPO) antibodies and autoimmune thyroiditis in a prospective study in the German population. Since scanty data are available in the literature on the prevalence of anti-TPO antibodies in children and adolescents without an increased risk for autoimmunity, we decided to assess the iodine excretion as well as the prevalence of anti-TPO antibodies in a large cohort of healthy children and adolescents. Moreover, these data were correlated to the results of ultrasound studies. In order to include a large number of patients a method for the measurement of antibodies to thyroid peroxidase (anti-TPO$\mathrm{Ab}$ ) in blood spots was established.

\section{Materials and methods}

\section{Probands}

The study was carried out from 1998 to 2000 in the city area of Berlin including children and adolescents living in the urban area. In co-operation with 15 local pediatricians data were collected from 660 volunteer children and adolescents, in whom a routine blood test, e.g. for cholesterol, blood counts and postvaccine antibody titers etc., became necessary. Informed consent was obtained and the study was approved by the local ethical committee. The ages ranged from 1 to 19 years, but most of the children $(73.6 \%)$ were aged between 9 and 14 years (median 11 years). Of the total, 293 were male (median age 12 years) and 367 were female (median age 11 years). Thyrotropin (TSH) and TPO measurements were completed in 648 probands, urinary iodine was measured in 540 probands and an ultrasound study was performed in 461 probands.

\section{Methods}

Questionnaire A questionnaire was filled out requesting date of birth, height, weight, familial thyroid disorders and iodine supplementation as well as underlying or chronic diseases.

Ultrasound study Sonography and measurements of thyroid volumes were carried out only by experienced pediatricians. Thyroid volume was assessed according to Brunn et al. (24). In both lobes length, width and depth were measured and volume was calculated with the following formula:

$$
\begin{aligned}
\text { volume of one lobe }(\mathrm{ml})= & \text { length } \times \text { width } \\
& \times \text { depth } \times 0.479
\end{aligned}
$$

Our own data of 1200 Berlin schoolchildren, which had been published previously (4), were used as agerelated reference values.

An altered echostructure was reported with special respect to an inhomogeneous echopattern typical for AIT.

Urinary iodine concentrations Iodine in urine was measured by the method of Sandel and Kolthoff (25) and was calculated as $\mu \mathrm{g}$ iodine to $\mathrm{g}$ creatinine $(\mu \mathrm{g}$ $\mathrm{I} / \mathrm{g}$ crea). A normal iodine intake is assumed with a concentration exceeding $100 \mu \mathrm{g} \mathrm{I/g}$ creatinine (2). Concentrations above $500 \mu \mathrm{g}$ iodine/g creatinine were regarded as contamination.

TSH determination TSH was measured in dried filter paper blood spots using an assay for neonatal screening - DELFIA Neonatal hTSH Test (Fa. Wallac Oy, Turku, Finland). TSH values above $4 \mathrm{mU} / \mathrm{l}$ were regarded as suspicious for an impaired thyroid function. For the blood spot assay the sensitivity is calculated till a value of $\leq 10 \mathrm{mU} / \mathrm{l}$ as normal.

Determination of anti-TPO antibodies in dried blood spots For the determination of anti-TPO-Ab a commercially available radioimmunoassay (RIA) DYNO test anti-TPO-Ab (Fa. BRAHMS, Berlin, Germany) for the quantitative measurement in serum was modified and adapted to the measurement in dried filter paper blood spots. Standards and controls (KI $150 \mathrm{U} / \mathrm{ml}$; KII $640 \mathrm{U} / \mathrm{ml}$ ) were established in whole antibody-free blood.

The cut-off for positivity was set at $100 \mathrm{U} / \mathrm{ml}$. The samples were measured in duplicate, quality criteria were assessed with 80 samples comparing serum and filter paper results.

\section{Statistical analysis}

For statistical analysis we used SPSS 7.5 for Windows (Statistical Package for Social Sciences). Significant differences were assessed with the Mann-Whitney $\mathrm{U}$ test or in the presence of a normal distribution with the Student's $t$-test. Correlations were calculated according to Pearson.

\section{Results}

\section{Anti-TPO-Ab assay}

The comparison of 80 samples with measurement of anti-TPO-Ab concentrations in serum and filter paper specimens revealed a specificity of $100 \%$ (all negative 
samples had a negative test result), a sensitivity of $91.94 \%$ (four positive serum samples with a titer between 100 and $134 \mathrm{U} / \mathrm{ml}$ were not found in the spot assay), a positive predictive value of $100 \%$ (the positive spot results are associated with a positive patient) and a negative predictive value of $88.57 \%$ (the negative spot result is associated with a negative patient). In 45 positive samples a correlation of 0.927 , with a regression equation of filter paper spot $=0.913 \times$ serum -32 284 was found. In Fig. 1 the regression curve and the $95 \%$ confidence intervals are illustrated.

The 20-times determination of samples with different antibody concentrations revealed an intra-assay coefficient of variation of $1.7-2.7 \%$, and in 17 subsequent assays an interassay coefficient of variation of $1.5-5.7 \%$ was found.

\section{Epidemiological study}

Urinary iodine concentrations The median urinary iodine concentration was $139 \mu \mathrm{g} \mathrm{I} / \mathrm{g}$ creatinine without a significant difference between males and females. of the probands $23.5 \%$ had a concentration below $100 \mu \mathrm{g} \mathrm{I} / \mathrm{g}$ creatinine indicating iodine deficiency according to the 1973 WHO standard (1). The iodine concentration of the probands is demonstrated in Fig. 2. A urinary iodine concentration $>500 \mu \mathrm{g} \mathrm{I} / \mathrm{g}$ creatinine was present in $17 \%$ of the probands and was regarded as contamination.

Iodine supplementation In $83.8 \%$ of families iodized household salt was used and daily iodine tablets containing $100 \mu \mathrm{g} \mathrm{I} /$ tablet were used by $5.3 \%$ of the probands.

Ultrasound study In $22 \%$ of all probands the thyroid volumes exceeded the reference values (mean +2 s.D.) of

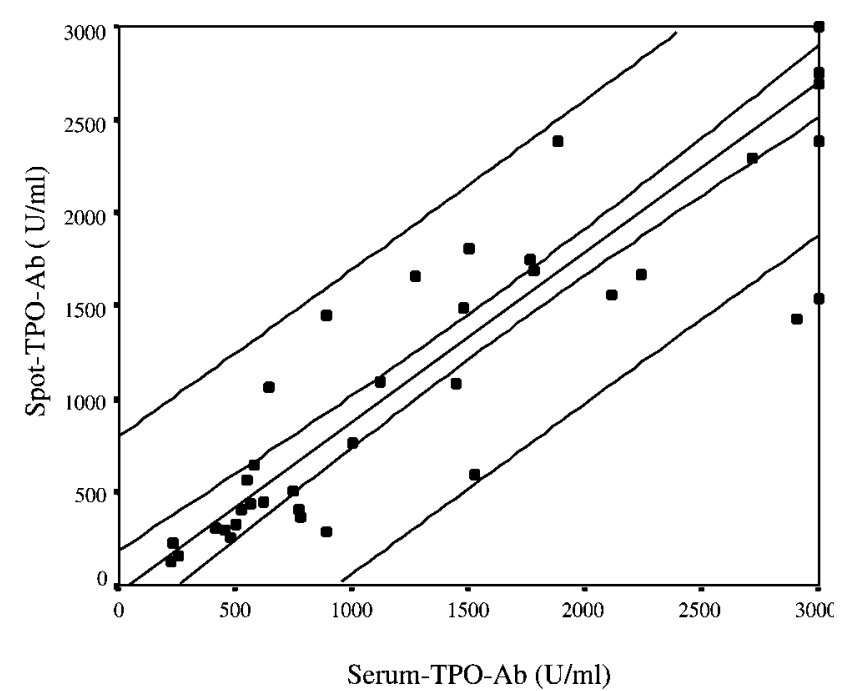

Figure 1 Correlation of serum and filter paper (spot) determinations of TPO-Ab with $95 \%$ confidence limits.

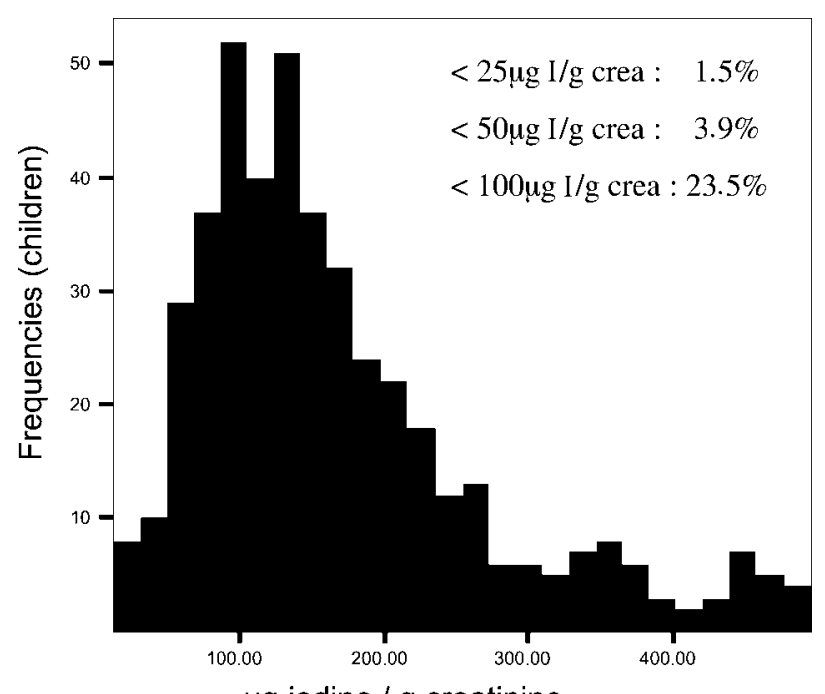

$\mu \mathrm{g}$ iodine $/ \mathrm{g}$ creatinine

Figure 2 Frequencies of the urinary iodine concentration of the probands.

normal schoolchildren of the same area (4), which might indicate selection of children and adolescents with increased neck volumes by the investigators. Using the WHO references only 9.3\% of the probands had an enlarged thyroid. The mean thyroid volume together with the standard deviation and the $25-75 \%$ percentile, and with the reference ranges are shown in a box blot diagram in Fig. 3. An altered echostructure was present in $10.3 \%$ of the probands

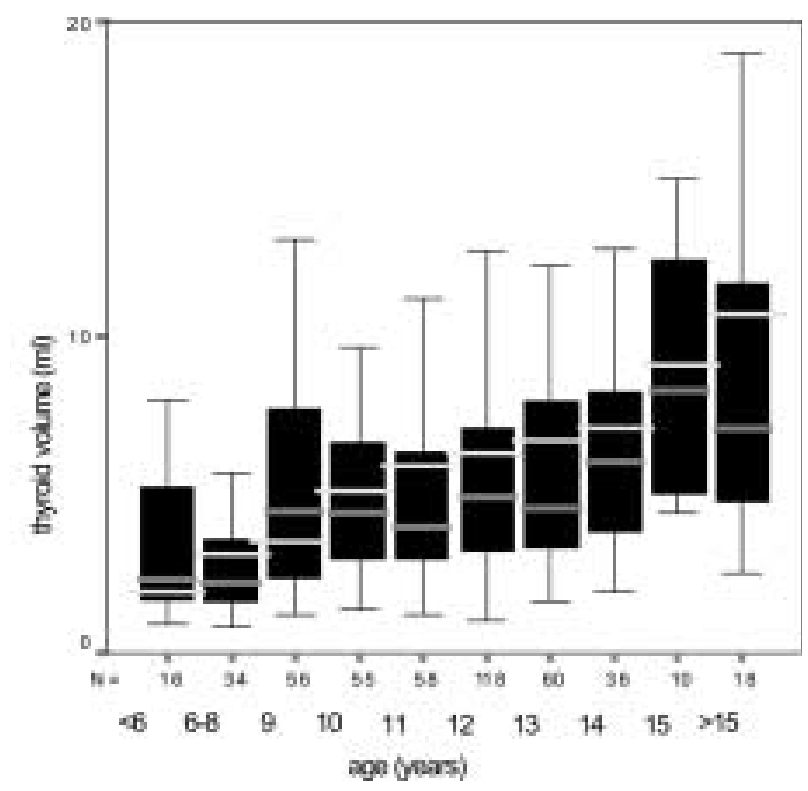

Figure 3 Box blot diagram of the mean thyroid volume with the standard deviation and the $25-75 \%$ percentile of the probands correlated to age. 
including small cystic lesions, inhomogeneous structure, and hyper- or hypoechogenicity.

TSH In 2.5\% of the probands the TSH concentration in dried filter paper blood spots was $>4 \mathrm{mU} / \mathrm{l}$. A clear indication for hypothyroidism with a concentration $>10 \mathrm{mU} / \mathrm{l}$ was found in only $0.8 \%$. The median TSH level was $1.1 \mathrm{mU} / \mathrm{l}$ without age- or gender-related differences.

\section{Prevalence of anti-TPO antibodies and autoimmune thyroiditis in children and adolescents}

Anti-TPO-Ab $(>100 \mathrm{U} / \mathrm{ml})$ were found in 22 children and adolescents resulting in a prevalence of $3.4 \%$. In females the prevalence was 2.7 times higher than in males (male:female ratio 6:16). The age and gender distribution of probands with positive anti-TPO-Ab is illustrated in Fig. 4. The median age of patients with positive anti-TPO-Ab was 12 years. The median anti-TPO-Ab concentration was $765 \mathrm{U} / \mathrm{l}$ (range: $110>3000$ U/l, see Fig. 5).

The urinary iodine concentration in probands with anti-TPO-Ab was $148 \mu \mathrm{g} \mathrm{I} / \mathrm{g}$ creatinine compared with $139 \mu \mathrm{g} \mathrm{I} / \mathrm{g}$ creatinine in the other probands. Thirtythree percent $(n=5)$ had a urinary iodine concentration below $100 \mu \mathrm{g} \mathrm{I} / \mathrm{g}$ creatinine (range 51-97 $\mu \mathrm{g} \mathrm{I/g}$ creatinine), which could indicate an iodine deficiency according to the 1973 WHO standard (1).

Of the anti-TPO-Ab positive probands 91\% used iodized salt; iodine tablets were not used in this group of probands.

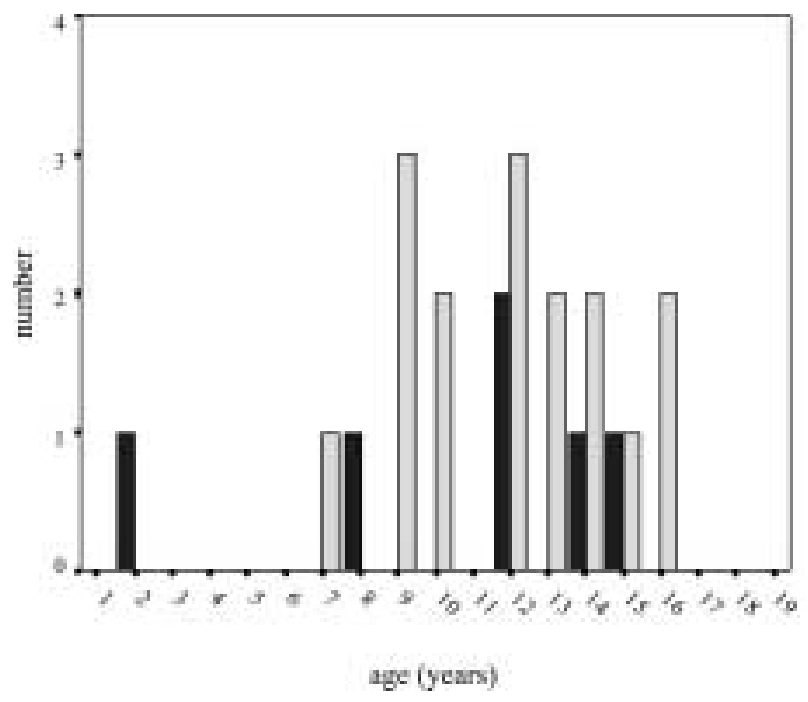

Figure 4 Age and sex distribution of the anti-TPO antibody positive probands. Dark grey bars, males; pale grey bars, females.

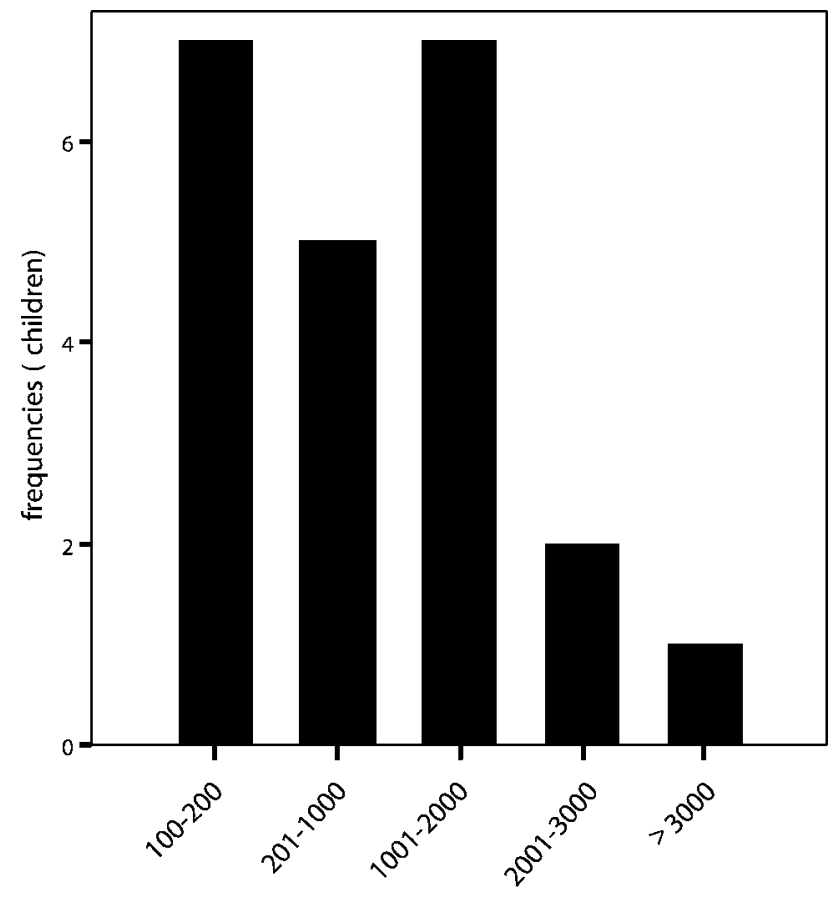

anti-TPO-ab (U/I)

Figure 5 Frequency of the anti-TPO-Ab titers in children and adolescents.

In eight of the 22 patients with anti-TPO-Ab no valid ultrasound investigation was available. Twelve of $14(86 \%)$ probands with positive antibodies and volume measured by ultrasound had an increased thyroid volume compared with the reference data (4). The median thyroid volume $(4.6 \mathrm{ml})$ of the anti-TPO-Ab negative probands was significantly different to the median thyroid volume $(7.6 \mathrm{ml})$ of anti-TPO-Ab positive patients $(P<0.001)$.

The echostructure of 12 anti-TPO-Ab positive patients revealed the typical findings of autoimmune thyroiditis with an inhomogeneous structure and scattered hypoechogenicity. Summarizing, one child of the positive anti-TPO-Ab patients had no sonographic sign of an AIT, another child had only an increased thyroid volume without any other sonographic signs. Thus the frequency of AIT in the study population defined by positive antibodies combined with pathological ultrasound findings, e.g. increased volume and scattered hypoechogenicity, was $3.0 \%$. Sixty percent of the probands with positive autoantibodies had a history of familial thyroid disorders compared with $42 \%$ in antibody negative probands.

A TSH concentration $>4 \mathrm{mU} / \mathrm{l}(4.5-146 \mathrm{mU} / \mathrm{l})$ was found in $5(23 \%)$ and $>10 \mathrm{mU} / \mathrm{l}(11-146 \mathrm{mU} / \mathrm{l})$ in 3 (14\%) patients with increased antibodies, with a significant correlation of TSH levels with anti-TPO-Ab titers $(r=0.524 ; P<0.05)$. 


\section{Discussion}

The goals of this pilot study were to assess the practicality of anti-TPO-Ab determination in dried filter paper blood spots and to get an estimate of the frequency of anti-TPO-Ab in healthy children and adolescents in an iodine replete area. However, since the selection of probands was performed by different local pediatricians, it cannot be excluded that a certain selection bias towards children with the appearance of enlarged thyroids exists, reflected by the high frequency $(22 \%)$ of increased thyroid volumes compared with previous reference data (4). According to the WHO standard thyroid volumes for the assessment of iodine deficiency (26) only $9.3 \%$ of the probands had an enlarged thyroid. The newly established method for the anti-TPO$\mathrm{Ab}$ determination may now serve as a tool for large prospective field studies in different countries.

The median urinary iodine concentration of $139 \mu \mathrm{g}$ iodine/g creatinine in these children and adolescents was comparable or even higher than in previous German studies $(4,27)$. A sufficient iodine supply in Berlin is also reflected by the goiter prevalence in the reference data of less than $10 \%$ as compared with WHO standards (26). This trend towards a normalization of iodine supply has been recognized also in other parts of Germany (28-30).

To estimate the anti-TPO-Ab prevalence and autoimmune thyroiditis in children and adolescents (31, 32), a simple method for the determination of antiTPO-Ab in dried filter paper blood specimens with a high specificity and, for screening purposes, sufficient sensitivity was established. The cut-off of $100 \mathrm{U} / \mathrm{ml}$ of this screening kit is acceptable, since clinically relevant forms of autoimmune thyroiditis in children and adolescents present with anti-TPO-Ab titers well above 200-400 U/ml using conventional tests (33).

So far few data of thyroid autoimmunity in large cohorts of children and adolescents are available. Only three recent studies reporting results of antibody concentrations in serum have been performed. However, only one Swedish study, reporting a frequency of $8 \%$ in a total population of 59 schoolchildren (34), measured anti-TPO-Ab with a sensitive immunological method, while another study from India, which described the prevalence of $7.2 \%$ in a large group of 1810 girls who were selected because of a goiter, only measured microsomal antibodies (35). The third study which took place in Sardinia with moderate iodine deficiency measured also microsomal or anti$\mathrm{TPO}-\mathrm{Ab}$ with a prevalence rate of $2.92 \%$, ranging from 0.0 to $7.3 \%$ depending on the community (36). The interpretation of these data in relation to this study is difficult as in Sardinia the prevalence of autoimmune diseases, e.g. insulin dependent diabetes mellitus is one of the highest in Europe (37). In this study in healthy children with no increased risk for autoimmunity a prevalence of positive anti-TPO-Ab of $3.4 \%$ with an increased frequency in girls (male to female ratio of $1: 2.7)$ is described which is also lower than in adults of iodine replete areas. Previous studies in adults have found a prevalence of up to $8 \%$ with a male to female ratio of $1: 2.1(38,39)$. In contrast, the prevalence in young adults was $3.38 \%$ to $6.5 \%$ (40). The prevalence of the anti-TPO-Ab determined in this study, therefore, is low compared with data from adults or aged populations and is similar to the prevalence in children as reported by Loviselli et al. (36). It cannot be excluded that with a more sensitive assay and serum determinations the frequency would have been higher. However, the relevance of low anti-TPO-Ab titers for thyroid diseases in children and adolescents is controversially discussed.

The further investigation of the children and adolescents with positive antibodies revealed a slightly higher urinary iodine concentration compared with the antibody negative group; however this difference did not reach statistical significance. There was also a trend towards a more frequent family history of thyroid disease but again without statistical significance, which might be due to the relatively small number of children with positive antibodies $(n=22)$.

Increased thyroid volume with typical lesions for autoimmune thyroiditis were found in $86 \%$ of the anti-TPO-Ab positive children and adolescents. A highly significant difference $(7.6 \mathrm{ml}$ vs $4.6 \mathrm{ml}$; $P<0.001$ ) was found between the median thyroid volume of antibody positive and antibody negative children. These are the leading symptoms of autoimmune thyroiditis in childhood and adolescence (41). Despite these findings, in $77 \%$ of the children with positive anti-TPO-Ab titers TSH was normal indicating a euthyroid state. Similar findings for TSH have been published previously (42), but as in other studies (38) we found a significant positive correlation $(r=0.524)$ of TSH levels and anti-TPO-Ab titers. This is compatible with the general finding that autoimmune thyroiditis in children is usually benign and without symptoms of hypo- or hyperthyroidism despite slightly elevated TSH levels (43). Spontaneous remission without treatment is frequent $(44,45)$.

We have confirmed the data indicating a normalization of iodine supply in schoolchildren and adolescents in Berlin. The reference data on anti-TPO-Ab prevalence $(3.4 \%)$ demonstrate a frequency comparable to young adults. The method used in this study is a useful tool for performing further prospective field studies to monitor the prevalence of autoimmune thyroiditis in the presence of a changing iodine supply.

\section{Acknowledgements}

The engaged and fruitful co-operation with the following pediatricians in private practice is deeply acknowledged. Without their efforts this study would not have 
been possible: W Stäblein, W Singendonk, E JägerRoman, H Litzenbörger, B Ehnert, S Krusche, A Scherer, G Heine, T Rakowski, C Köpcke, H Koch, A KarstenKlumpp, A Nahler, G Kalisch, E Meidinger, U Wachholz, F Schulze, D Kahn, J Plieth, U Fegeler, F Ulbricht and S Knies. Furthermore we thank BRAHMS, Berlin, for the kind supply of reagents to establish the filter paper method.

\section{References}

1 Stadieneinteilung des Jodmangels nach. WHO 1973.

2 Hesse V. Iodprophylaxe bei Kindern. Blackwell Wissenschafts-Verlag Berlin 199721.

3 Hesse V, Böttcher M, Herlinghaus C, Kroschwald P \& Oehler K. Monitoring der Uriniodausscheidung von Neugeborenen als Kriterium der Wirkung einer Iodprophylaxe - Verlaufsbeobachtung von 1980 bis 1998. In 3. Interdisziplinäres Jodsymposium, Aktuelle Aspekte des Jodmangels und des Jodüberschusses. Hrsg. Bauch K 2000 41-50.

4 Liesenkötter KP, Kiebler A, Stach B, Willgerodt H \& Grüters A. Small thyroid volumes and normal iodine excretion in Berlin schoolchildren indicate full normalization of iodine supply. Experimental and Clinical Endocrinology and Diabetes 1997105 (Suppl 4) 46-50.

5 Braverman LE. Iodine induced thyroid disease. 3rd Thyroid Symposium. Aacta Medica Austriaca $199017 / 90$ Sonderheft 1 pp 30.

6 Nagataki S, Yamashita S \& Tamai H. Immunogenetics of autoimmune endocrine disease. In Autoimmune diseases of endocrine system, pp 51-72. Ed. R Volpé. Boca Raton: CRC Press, 1990.

7 Schleusener H, Bogner U, Peters H, Kotulla P, Schmieg D, Grüters A et al. The relevance of genetic susceptibility in Graves' disease and immune thyroiditis. Experimental and Clinical Endocrinology $199197127-132$.

8 Plotnikoff N, Murgo A, Faith R \& Wybran J. Stress and immunity. Boca Raton: CRC, 1991 51-72.

9 Glaser R \& Kiecolt-Glaser JK. Handbook of human stress and immunity, pp 1-414. San Diego and London: Academic Press, 1994.

10 Holt PG. Immune and inflammatory function in cigarette smokers. Thorax 198742 241-249.

11 Behrman RE, Kliegman RM \& Arvin AM. Nelson Textbook of Pediatrics, edn 15, pp 1595. Auflage 1996.

12 Nelson JL \& Steinberg AD. Sex steroids, autoimmunity and autoimmune disease. In Hormones and Immunity, pp 93-119. Eds I Berczi \& K Kovacs. Lancaster, UK: MTP Press, 1987.

13 Volpé R. Autoimmune thyroid disease. In Contempory Endocrinology: Disease of the thyroid. Ed. LE Braverman. Towa NJ: Humana Press, 1997.

14 Mariotti S, Loviselli A, Cambosu A, Velluzi F, Atzeni F, Martino E et al. The role of iodine in autoimmune thyroid disease in human. In The Thyroid and Iodine, pp 155-168. Eds J Nauman, D Glinoer, LE Braverman \& U Hostalek. Stuttgart/New York, 1996.

15 Follis RH Jr. Further observations on thyroiditis and colloid accumulation in hyperplastic thyroid glands of hamsters receiving excess iodine. Laboratory Investigations 196413 1590-1599.

16 Bagchi N, Brown TR, Urdanivia E \& Sundick RS. Induction of autoimmune thyroiditis in chicken by dietary iodine. Science $1985230325-327$.

17 Allen EM, Appel MC \& Braverman LE. The effect of the iodide ingestion on the development of spontaneous lymphocytic thyroiditis in the diabetes-prone BB/W rat. Endocrinology 1986 118 1977-1981.

18 Mooij P, de Wit HJ, Bloot AM, Wilders-Truschnig MM \& Drexhage HA. Iodine deficiency induces thyroid autoimmune reactivity in Wistar rats. In The Thyroid, Iodine and Autoimmunity, pp 51-83. Ed. P Mooij. Rotterdam, Thesis, 1993.
19 Weaver DK, Nishiyami RH, Burton WD \& Batsakis JG. Surgical thyroid disease. A survey before and after iodine prophylaxis. Archives of Surgery 196692 796-801.

20 Boukis MA, Koutras DA, Souvatzolglou A, Evangelopoulou A, Vrontakis M \& Moulopoulos SD. Thyroid hormone and immunological studies in endemic goiter. Journal of Clinical Endocrinology and Metabolism 198357 859-862.

21 Koutras DA, Karaiskos KS, Evangelopoulou K, Boukis MA, Piperingos GD, Kitsopanides J et al. Thyroid autoantibodies after iodine supplementation. In The Thyroid and Autoimmunity, pp 211-212. Eds HA Drexhage \& WM Wiersinga. Amsterdam: Excerta Medica, 1986.

22 Monteiro E, Galváo-Teles A, Santos ML, Mouráo L, Correia MJ \& Lopo Tuna J. Antithyroid antibodies as an early marker for thyroid disease induced by amiodarone. British Medical Journal 1986 $292227-228$.

23 Martino E, Macchia E, Aghini-Lobardi F, Antonelli A, Lenziardl M, Concetti $\mathrm{R}$ et al. Is humoral thyroid autoimmunity relevant in amiodarone iodine-induced thyrotoxicosis (AIT)? Clinical Endocrinology $1986 \mathbf{2 4} 627-633$.

24 Brunn J, Block U, Ruf I, Kunze WP \& Scriba PC. Volumetrie der Schilddrüsenlappen mittels Real-time Sonographie. Deutsche Medizinische Wochenschrift 1981106 1338-1340.

25 Sandel EB \& Kolthoff IN. Microdetermination of iodine by catalytic method. Microchemica Acta 19371 9-15.

26 Delange F, Benker G, Caron P, Eber O, Ott W, Peter F et al. Thyroid volume and urinary iodine in European schoolchildren: standardization of values for assessment of iodine deficiency. European Journal of Endocrinology 1997136 180-187.

27 Gutekunst R, Magiera U \& Teichert HM. Jodmangel in der Bundesrepublik Deutschland. Medizinisch Klinik $1993 \mathbf{8 8}$ 525-528.

28 Willgerodt H, Keller E, Perschke C \& Stach B. The status of iodine nutrition in newborn infants, schoolchildren, adolescents and adults in former East Germany. Experimental and Clinical Endocrinology and Diabetes 1997105 (Suppl 4) 38-42.

29 Hampel R, Gordealla A, Zollner H, Klinke D \& Demuth M. Continuous rise of urinary iodine excretion and drop in thyroid gland size among adolescents in Mecklenburg-West-Pomerania from 1993 to 1997. Experimental and Clinical Endocrinology and Diabetes $2000 \mathbf{1 0 8} 197-201$.

30 Rendl J, Juhran N \& Reiners C. Thyroid volumes and urinary iodine in German school children. Experimental and Clinical Endocrinology and Diabetes 2001109 8-12.

31 Finke R, Bogner U, Kotulla P \& Schleusener H. Anti-TPO antibody determinations using different methods. Experimental and Clinical Endocrinology $1994 \mathbf{1 0 2} 145-150$.

32 Hunter I, Greene SA, McDonald TM \& Morris AD. Prevalence and aetiology of hypothyroidism in the young. Archives of Diseases in Childhood 200083 207-210.

33 Feldt-Rasmussen U, Høier-Madsen M, Bech K, Blichert-Toft M, Bliddal H, Date B et al. Anti-thyroid peroxidase antibodies in thyroid disorders and non-thyroid autoimmune diseases. Autoimmunity $19919245-253$.

34 Milakovic M, Berg G, Eggertsen R, Lindstedt G \& Nystrom E. Screening for thyroid disease of 15-17 year old schoolchildren in an area with normal iodine intake. Journal of Internal Medicine $2001250208-212$.

35 Marhawa RK, Tandon N, Karak AK, Gupta N, Verma K \& Koupillai N. Hahimoto's thyroiditis countrywide screening of goitrous healthy girls in postiodization phase in India. Journal of Clinical Endocrinology and Metabolism 200085 3798-3802.

36 Loviselli A, Velluzzi F, Mossa P, Cambosu MA, Secci G \& Atzeni F. The Sardinian autoimmunity study: 3. Studies on circulating antithyroid antibodies in Sardinian schoolchildren: relationship to goiter prevalence and thyroid function. Thyroid $2001 \mathbf{1 1}$ 849-857.

37 Songini M, Bernardinelli L, Clayton D, Montomoli C, Pascutoo C, Ghisland M et al. The Sardinian IDDM study: 1. Epidemiology and geographical distribution of IDDM in Sardinia during 1989 to 1994. Diabetologia $199841221-227$. 
38 Konno N, Yuri K, Taguchi H, Miura K, Taguchi S, Hagiwara K et al. Screening for thyroid disease in an iodine sufficient area with sensitive thyrotrophin assays, and serum thyroid autoantibody and urinary iodide determinations. Clinical Endocrinology 199338 273-281.

39 Prentice LM, Phillips DIW, Sarsero D, Beever K, McLachlan SM \& Smith BR. Geographical distribution of subclinical autoimmune thyroid disease in Britain: a study using highly sensitive direct assays for autoantibodies to thyroglobulin and thyroid peroxidase. Acta Endocrinologica 1990123 493-498.

40 Rallison ML, Dobyns BM, Meikle AW, Bishop M, Lyon JL \& Stevens W. Natural history of thyroid abnormalities: prevalence, incidence, and regression of thyroid disease in adolescents and young adults. American Journal of Medicine 199191 363-370.

41 Grüters-Kieslich A \& Willgerodt H. Struma diffusa. Pädiatrische Leitlinien $1999127-28$.
42 Jakšic J, Dumic M, Filipovic B, Ille J, Cvijetic M \& Gjuric G. Thyroid disease in a school population with thyromegaly. Archives of Diseases in Childhood 199470 103-106.

43 Moore DC. Natural course of 'subclinical' hypothyroidism in childhood and adolescence. Archives of Pediatric and Adolescent Medicine 1996150 293-297.

44 Mäenpää J, Raatikka M, Räsänen J, Taskinen E \& Wager O. Natural course of juvenile autoimmune thyroiditis. Journal of Pediatrics 1985107 898-904.

45 Rallison ML, Dobyns BM, Keating FR, Rall JE \& Tyler FH. Occurrence and natural history of chronic lymphocytic thyroiditis in childhood. Journal of Pediatrics 197586 675-682.

Received 25 February 2002

Accepted 4 November 2002 